\title{
Surto de varíola bovina causada pelo vírus Vaccinia na região da Zona da Mata Mineira
}

\author{
[Outbreak of exantemal disease caused by Vaccinia virus in human and cattle in \\ Zona da Mata region, Minas Gerais] \\ Z.I.P. Lobato ${ }^{1}$, G.S. Trindade ${ }^{2}$, M.C.M. Frois ${ }^{3}$, E.B.T. Ribeiro ${ }^{1}$, G.R.C. Dias ${ }^{1}$, \\ B.M. Teixeira ${ }^{1}$, F.A. Lima ${ }^{1}$, G.M.F. Almeida ${ }^{2}$, E.G. Kroon ${ }^{2}$ \\ ${ }^{1}$ Escola de Veterinária da UFMG \\ Caixa Postal 567 \\ 30123-970 - Belo Horizonte, MG \\ ${ }^{2}$ Instituto de Ciências Biológicas - UFMG \\ ${ }^{3}$ Instituto Mineiro de Agropecuária - IMA
}

\begin{abstract}
RESUMO
Relata-se um surto de doença exantemática, caracterizada como varíola bovina, acometendo bovinos e seres humanos na Zona da Mata Mineira. Setenta e duas propriedades, distribuídas em 20 municípios localizados na região, foram visitadas para se levantar os aspectos clínicos e epidemiológicos da doença. Detectaram-se 1020 vacas doentes durante a investigação, quando houve queda na produção do leite associada a infecções bacterianas secundárias. Casos humanos foram registrados em $83 \%$ das propriedades visitadas. Espécimes clínicos e amostras de soro foram coletados dos animais doentes ou convalescentes. O diagnóstico de laboratório mostrou o envolvimento de um ortopoxvírus, precisamente o Vaccinia virus como agente etiológico do surto.
\end{abstract}

Palavras-chave: varíola bovina, zoonose, ortopoxvírus, vírus Vaccinia

\begin{abstract}
It was investigated an outbreak of exantemal disease in human and cattle in Zona da Mata region, Minas Gerais's State, Brazil. Seventy two farms located in 20 counties locating in this region were visited and disease pattern was studied. 1020 cows got sick in the visited herds and in $83 \%$ of them human cases occurred together with disease in animals. Drop in milk production and secondary infection were frequently observed. The disease occurred mainly from may to September. Serum and scars from sick and convalescent animals were collected and laboratory diagnostic showed that an orthopoxvirus, more precisely vaccinia virus was involved in the outbreak.
\end{abstract}

Keywords: exantemal disease, zoonosis, orthopoxvirus, Vaccinia virus

\section{INTRODUÇÃO}

O termo varíola bovina é, muitas vezes, utilizado popularmente para descrever uma doença caracterizada pelo aparecimento de lesões cutâneas localizadas nos tetos das vacas, apesar de três diferentes poxvírus poderem estar envolvidos na sua etiologia. Dentro do gênero Orthopoxvirus, os vírus da varíola bovina, o cowpox genuíno e o Vaccinia virus, utilizados na campanha de vacinação contra a varíola humana, podem causar esse tipo de lesão. O primeiro tem, de acordo com a literatura, distribuição restrita ao continente europeu e o último, distribuição desconhecida (Fenner, 2000; Lewis-Jones, 2004). As lesões causadas por eles apresentam-se nas formas proliferativas, ulceradas ou em crostas. Quando os vírus atingem a pele, observa-se o desenvolvimento de eritema cutâneo característico, que se inicia com o

Recebido para publicação em 6 de julho de 2004

Recebido para publicação, após modificações, em 28 de fevereiro de 2005

E-mail: ziplobat@vet.ufmg.br 
aparecimento de pequenas manchas, as quais evoluem para vesículas, pústulas e crostas que terminam por cicatrizar (Breman e Henderson, 2002). Dentro do gênero Parapoxvirus, o vírus da pseudovaríola tem distribuição mundial e causa lesões clinicamente muito semelhantes às produzidas pelos ortopoxvírus, sendo essa uma doença de ocorrência muito freqüente em nosso meio. Clinicamente, essas enfermidades são bastante semelhantes, principalmente quanto à evolução dos sinais clínicos, entretanto as infecções causadas por parapoxvírus geralmente são mais brandas que as causadas pelos outros dois vírus. Todas elas são zoonoses e provocam no homem lesões semelhantes às descritas para os bovinos, localizadas principalmente nas mãos e, mais raramente, nos braços e antebraços (Mazur et al., 2000; Moss, 2001; Lewis-Jones, 2004) .

A transmissão dessas enfermidades entre os animais ocorre principalmente através das mãos dos ordenhadores ou equipamentos de ordenha mecânica, e a penetração dos vírus se dá por soluções de continuidade em lesões preexistentes nos tetos das vacas (Damaso et al., 2000; Schatzmayr et al., 2000, Trindade et al., 2003). A doença também pode ser transmitida dos animais aos seres humanos, que se infectam por meio do contato com as lesões presentes nos tetos dos animais.

No Brasil, pesquisadores registraram esse tipo de enfermidade de ocorrência esporádica, principalmente, nas décadas de 50 a 70 , nos estados da região Sudeste (Silva et al., 1986). Desde o final da década de 90, têm-se registrado vários surtos de uma doença semelhante à varíola bovina em diferentes regiões do país, como no Vale do Paraíba, SP, no município de Cantagalo, RJ, e no Mato Grosso do Sul (Fagliari et al., 1999; Damaso et al., 2000; Schatzmayr et al., 2000; Trindade et al., 2003). Esses surtos comprometeram centenas de propriedades em todas as regiões e acarretaram grande perda econômica devido à diminuição na produção de leite e à ocorrência de mamite e outras contaminações bacterianas secundárias. Em muitos surtos, o diagnóstico laboratorial do ortopoxvírus foi feito a partir do isolamento viral, pela microscopia eletrônica e sorologia e, em alguns casos, por técnicas de biologia molecular como a PCR (Damaso et al., 2000; Trindade et al., 2003).
Em meados de 2001, foi relatado por produtores rurais e veterinários da região da Zona da Mata de Minas Gerais um grande número de casos clínicos em seres humanos e bovinos, com sintomas semelhantes aos causados por alguns vírus da família Poxviridae. Este trabalho teve como objetivo inicial caracterizar essa enfermidade do ponto de vista clínico e epidemiológico e, posteriomente, isolar e identificar o vírus envolvido nos surto.

\section{MATERIAL E MÉTODOS}

Durante o mês de outubro de 2001, foram visitadas 72 propriedades em 20 municípios da região da Zona da Mata, percorrendo-se cerca de $5700 \mathrm{~km}$ (Tab. 1). Os funcionários do Instituto Mineiro de Agropecuária (IMA) reconstituíram o universo de algumas fazendas onde o problema estava ocorrendo ou tinha sido recentemente relatado. Aplicaram-se questionários com o objetivo de obter informações sobre a propriedade, ordenhadores, evolução dos sinais clínicos, prejuízos causados e transmissão da doença. Realizaram-se exames clínicos e coleta de material dos animais. Coletaram-se amostras de lesões cutâneas (crostas) de 19 animais, em 12 propriedades, e amostras de sangue de 55 animais, em 26 propriedades.

Tabela 1. Municípios da Zona da Mata de Minas Gerais e número de propriedades visitadas

\begin{tabular}{cc}
\hline Município & $\mathrm{N}^{0}$ de propriedades \\
\hline Leopoldina & 7 \\
Argirita & 3 \\
Laranjal & 2 \\
Pirapetinga & 2 \\
Volta Grande & 1 \\
Cataguases & 3 \\
Astolfo Dutra & 1 \\
Dona Eusébia & 6 \\
Miraí & 8 \\
Santana de Cataguases & 1 \\
Rio Pomba & 2 \\
Guarani & 6 \\
Piau & 1 \\
Piraúba & 5 \\
Ubá & 1 \\
Muriaé & 3 \\
Antônio Prado & 2 \\
Barão de Monte Alto & 6 \\
Eugenópolis & 9 \\
Vieiras & 3 \\
Total & 72 \\
\hline
\end{tabular}


O material coletado das lesões foi triturado em meio mínimo de eagle (MEM) sem soro fetal bovino (SFB), acrescido de penicilina $(500 \mathrm{U} / \mathrm{ml})$ e fungizona $(25 \mu \mathrm{g} / \mathrm{ml})$. Ovos embrionados de galinha, com 10 dias de idade, foram inoculados na membrana corioalantóide (MCA) com $0,1 \mathrm{ml}$ da suspensão pela técnica convencional (Diniz et al., 2001). As membranas foram coletadas assepticamente após a incubação dos ovos em estufa a $37^{\circ} \mathrm{C}$ por 72 horas. Como controle negativo, alguns ovos foram inoculados com MEM ou solução salina. Os controles positivos foram realizados com o Vaccinia virus amostra Western Reserve (WR). As membranas que apresentaram lesões foram trituradas em solução de PBS e congeladas a $-70^{\circ} \mathrm{C}$ para a infecção de células Vero.

Seis amostras de soro coletadas das vacas doentes e uma de um ordenhador com lesões nos dedos e palmas das mãos foram submetidas ao teste de soroneutralização por inibição do número de placas. Foram realizadas diluições dos soros a partir de $1 / 10$ na razão de 2 até 1/5120. O Vaccinia vírus, amostra WR, foi diluído em MEM sem SFB até a concentração de $10^{3}$ partículas virais/ml que geravam cerca de 50 placas de lise por câmara. As misturas (soro/vírus) foram mantidas sob agitação a $37^{\circ} \mathrm{C}$ por 1 hora e distribuídas em placas de 24 câmaras contendo a monocamada de células Vero e incubadas até o aparecimento do CPE. Após 48 horas, o meio foi desprezado e as células fixadas por 15 minutos em solução $10 \%$ de formol em PBS. A monocamada foi corada com solução de cristal violeta durante cinco a 15 minutos. Os ensaios foram feitos em triplicata para todos os soros testados. Foram feitos, também, controles de células, de vírus e do soro. O soro-controle foi o anti-Vaccínia WR, produzido em coelhos no Laboratório de Vírus do Instituto de Ciências Biológicas-UFMG. O título do soro foi calculado pelo inverso da diluição capaz de neutralizar $50 \%$ do número de placas de lise detectadas nos controles. Títulos maiores ou iguais a $1 / 10$ foram considerados positivos.

A reação em cadeia pela polimerase (PCR) foi realizada utilizando-se quatro genes característicos dos ortopoxvírus que codificam a enzima timidina quinase (TK), o fator de crescimento do Vaccinia virus (VGF), a proteína do corpúsculo de inclusão do tipo A (ATI) e a hemaglutinina viral (HA). As PCR foram realizadas a partir dos DNAs extraídos das membranas e células inoculadas e seguiram os mesmos protocolos descritos por Fonseca et al. (1998) e Trindade et al. (2003). Após a amplificação por PCR, algumas amostras foram seqüenciadas pelo método de Sanger et al. (1977) e outras submetidas aos ensaios de polimorfismo de tamanho de fragmento de restrição (RFLP) utilizando-se o protocolo de digestão enzimática descrito por Meyer et al. (1997).

\section{RESULTADOS}

Com base nas visitas e nos questionários, registraram-se que 1020 vacas em lactação adoeceram e que em $63 \quad(87,5 \%)$ das propriedades ocorreram 110 casos em humanos, concomitante aos em bovinos. Observaram-se lesões vesiculares nos dedos de ordenhadores e tetos das vacas que evoluíram para pústulas, crostas e feridas erosivas (Fig. 1A-D). Em humanos, também foram registrados linfoadenopatia axilar, prurido intenso e febre. Em $55 \%$ das vacas e $63 \%$ dos seres humanos acometidos, o curso da doença foi de 15 a 30 dias. Observou-se que, mesmo na presença de lesões nos tetos, na maioria das propriedades visitadas, a ordenha manual era feita sem a utilização de luvas (Fig. 1A).

A ocorrência da doença foi detectada pelo menos em uma propriedade em todos os meses do ano, com exceção de dezembro, porém $72 \%$ dos casos ocorreram de julho a setembro.

Em 92\% das propriedades com ocorrência da doença, realizava-se ordenha manual. A taxa de ataque nas vacas em lactação (número de vacas em lactação doentes/número total de vacas em lactação X 100) submetidas à ordenha manual foi entre 80 e $100 \%$ e nas de ordenha mecânica, entre 25 e $30 \%$.

Entre os animais acometidos, $43 \%$ apresentaram mamite ou outro tipo de infecção secundária durante ou após o aparecimento dos sinais clínicos e, em $68 \%$ das fazendas visitadas, de acordo com informações do proprietário, foi registrada queda na produção de leite. Em 66\% delas, a queda variou de 30 a 50\%. 
Em 21\% das propriedades, foi mencionada a doença em bezerros. Porém, como as lesões localizavam-se principalmente na gengiva e raramente nos lábios e na região do focinho, acredita-se que essa porcentagem possa ter sido maior, pois nem sempre o proprietário fazia exame detalhado que possibilitasse constatar a presença das lesões.

A taxa de ataque em humanos (número de ordenhadores doentes/número total de ordenhadores) variou entre 75 a $100 \%$ em mais da metade das propriedades. Apesar da dificuldade de locomoção, a maioria dos doentes residia na zona rural, $83 \%$ procuraram atendimento médico. Do total dos 110 trabalhadores que adoeceram, 24,6\% tinham menos de 25 anos e, com certeza, não receberam vacina contra varíola humana. Em cinco propriedades, foram relatados casos com lesões semelhantes em outras pessoas da família, que viviam na mesma casa, caracterizando provável transmissão horizontal entre humanos.

As MCAs inoculadas com material das crostas apresentaram lesões brancas e opacas, não hemorrágicas e típicas de infecção por ortopoxvírus (Fig. 2) ou, mais precisamente por Vaccinia virus (Diniz et al., 2001; Trindade et al., 2003).

Nos ensaios de soroneutralização, as amostras de soro bovino (Tab. 2) e a amostra coletada do ordenhador foram positivas, caracterizando a presença de anticorpos contra o gênero ortopoxvírus.

Quatro genes conservados no gênero Orthopoxvirus (TK, VGF, ATI e HA) foram amplificados. Das 12 amostras submetidas à PCR, sete foram positivas para o gene TK, nove para o VGF, sete para o ATI e quatro para o HA. Após a amplificação, alguns produtos correspondentes à região codificadora do gene TK foram seqüenciados e apresentaram cerca de $99 \%$ de similaridade com as seqüências de Vaccinia virus depositadas em banco de dados. Em relação aos testes de RFLP do gene ATI, o perfil de bandas obtido após a digestão enzimática foi semelhante ao perfil observado para o Vaccinia virus (dados não mostrados).

Tabela 2. Resultado da soroneutralização (SN) para ortopoxvírus em soros de bovinos, sinais clínicos e tempo da doença na propriedade

\begin{tabular}{lccc}
\hline Animal & Resultado da & $\begin{array}{c}\text { Sinal clínico } \\
\text { observado }\end{array}$ & $\begin{array}{c}\text { Tempo de aparecimento da doença } \\
\text { propriedade (dias) }\end{array}$ \\
\hline Espanha & SN & Crostas & 30 \\
Medalha & Pos & Úlceras & 15 \\
Vanessa & Neg & Crostas & 40 \\
Cuíca & Pos & Lesões cicatrizadas & 90 \\
Catarina & Pos & Crostas & 60 \\
Saracura & Pos & Crostas & 90 \\
\hline
\end{tabular}

\section{DISCUSSÃO}

Sabe-se que infecções causadas por poxvírus, especialmente por parapoxvírus, são amplamente distribuídas no Brasil e que, nas décadas de 60 e 70, durante a campanha de erradicação da varíola, casos esporádicos de infecções causadas por ortopoxvírus, precisamente pelo vírus vacinal, eram comumente relatados. Ainda na década de 80, alguns surtos de doença exantemática causada por ortopoxvírus, acometendo o gado bovino foram descritos. Entretanto, nos últimos cinco anos, tem-se observado aumento alarmante da ocorrência de surtos de varíola bovina em diferentes estados brasileiros, especialmente no estado de Minas Gerais (Damaso et al., 2000; Trindade et al., 2003; Nagasse-Sugahara et al., 2005). Considerando-se que esse estado é responsável por cerca de um terço da produção nacional de leite, a investigação dos aspectos epidemiológicos relacionados aos surtos de varíola bovina, bem como a rápida detecção e identificação dos agentes virais envolvidos, são importantes para minimizar a transferência e a disseminação da doença. 

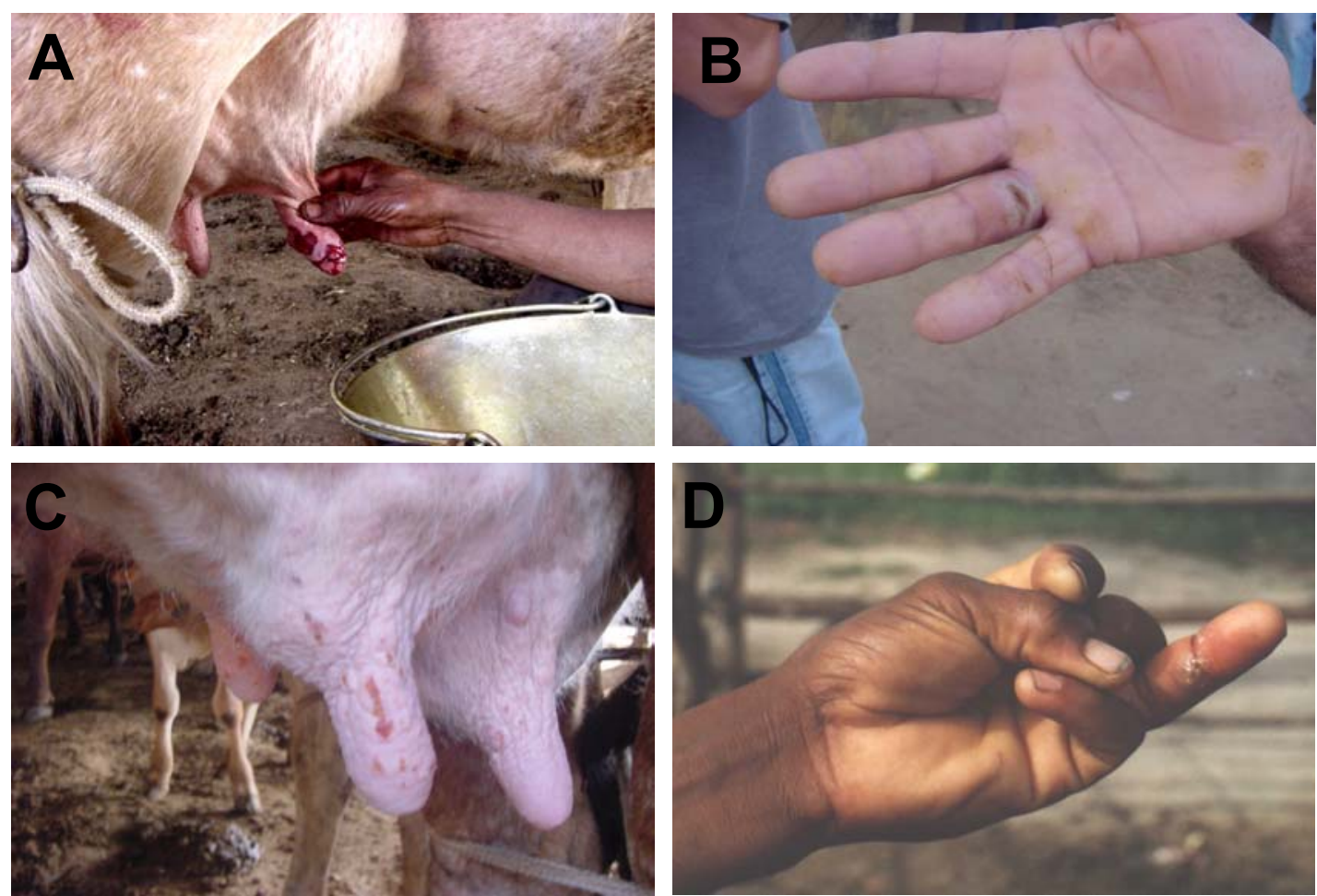

Figura 1. Sinais clínicos típicos de varíola bovina observados nos animais (A e C) e seres humanos (B e D) durante o surto da doença. A evolução das lesões nos tetos das vacas mostra lesões caracterizadas pela formação de pequenas vesículas na fase inicial (1C) e lesões em forma de crostas e feridas erosivas (1A).

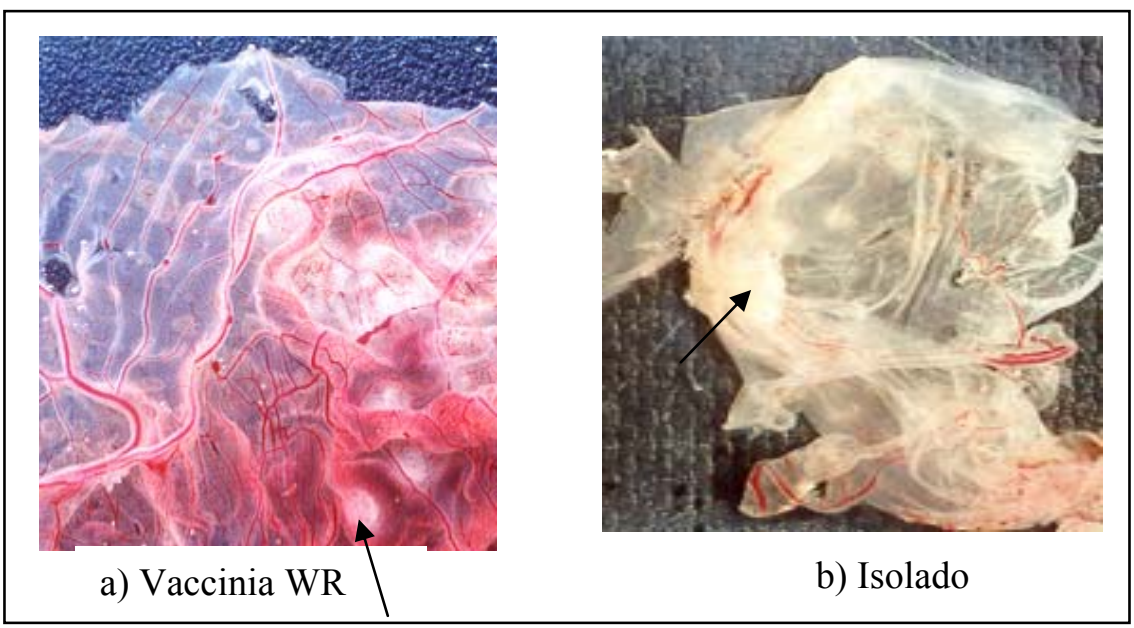

Figura 2. Membranas corioalantóide de embrião de galinha inoculadas com material das crostas (b) e com Vaccinia virus WR (a). 
A partir dos dados epidemiológicos obtidos e dos diagnósticos biológico e molecular, constatou-se que o surto de varíola bovina descrito foi causado por um ortopoxvírus da espécie Vaccinia virus.

A partir da visitação feita pelo Instituto Mineiro de Agropecuária e pela Escola de Veterinária da UFMG, vários aspectos epidemiológicos do surto foram relacionados, e dados sobre as características das propriedades visitadas, distribuição sazonal das ocorrências, sintomatologia típica e curso de evolução da doença foram apresentados.

Nas propriedades com ordenha mecânica, a taxa de ataque em humanos e animais foi mais baixa, provavelmente atribuída às medidas de desinfecção dos tetos. A provável veiculação dos vírus em latões de leite foi suscitada como uma das hipóteses para explicar a transmissão da doença entre as propriedades, pois apenas $26,6 \%$ delas possuíam tanque de expansão.

Ainda em relação à transmissão da doença, observou-se que alguns ordenhadores trabalhavam alternadamente em diferentes propriedades, fato responsável pela introdução da doença em algumas fazendas. Em todas elas, os ordenhadores não utilizavam luvas (Fig. 1A), mesmo após o aparecimento da doença clínica nas vacas. Adicionalmente, outros ordenhadores eram contratados pela impossibilidade de trabalho daqueles já infectados e, da mesma forma, continuavam ordenhando os animais sem luvas, mostrando desconhecimento da associação da doença nas vacas e nos homens.

Observou-se tendência à sazonalidade, com concentração dos casos nos meses de julho a setembro, que coincidiu com o período de seca. Isso poderia estar relacionado a fatores, ainda não identificados, que facilitariam a transmissão da doença e a circulação do vírus nessa época do ano. Em $84 \%$ das propriedades, houve relatos da presença de roedores, animais sabidamente susceptíveis à infecção pelo Vaccinia vírus, enquanto dados da literatura informaram $o$ isolamento de poxvírus de roedores silvestres (Diniz et al 2001; da Fonseca et al 2002). Outro aspecto é que, na época da seca, há possibilidade de maior ocorrência de traumatismos nos tetos, pois a pele pode apresentar-se ressecada, aumentando o número das soluções de continuidade e abrindo caminho para infecção viral.

Várias hipóteses foram levantadas na tentativa de elucidar fatores que desencadearam o início do surto e as formas de transmissão da infecção. Recentemente, foi relatado o isolamento dos vírus Cantagalo e Araçatuba, em surtos exantemáticos ocorridos em bovinos e em humanos nos municípios de Cantagalo, RJ, e Araçatuba, SP (Damaso et al., 2000; Schatzmayr et al., 2000; Trindade et al., 2003). As características clínicas da doença, como a presença de pápulas nos tetos e úbere que evoluíam para formas vesiculares e pustulares, assemelharam-se às observadas na Zona da Mata Mineira. Também as análises moleculares permitiram inferir que os vírus Araçatuba e Cantagalo assemelhavam-se a uma amostra de Vaccinia virus vacinal, o Vaccinia virus IOC, utilizada no estado do Rio de Janeiro, na época da campanha de vacinação em massa contra a varíola. A hipótese apontada para esse fato é que provavelmente a amostra vacinal teria sido mantida na natureza, estabelecendo ciclos de transmissão em algum animal nativo indeterminado, que poderia estar transmitindo o vírus para as vacas e essas para os ordenhadores (Damaso et al., 2000; Trindade et al., 2003).

A inoculação em MCA é, freqüentemente, utilizada para o diagnóstico de ortopoxvírus. $\mathrm{O}$ princípio desse teste baseia-se no fato de que as lesões produzidas por amostras de Vaccinia virus em MCA não se apresentam hemorrágicas como as produzidas por Cowpox vírus, permitindo o diagnóstico diferencial entre as duas espécies virais (Buller e Palumbo, 1991; Fenner et al., 1989). Entretanto, alterações na técnica de inoculação ou qualquer problema de manuseio e incubação dos ovos podem acarretar hemorragias na membrana, freqüentemente confundidas com as lesões hemorrágicas (Fenner, 1989; Trindade et al., 2003). Nas inoculações em MCA, não se visualizaram lesões hemorrágicas.

A soroneutralização contribuiu para a identificação das amostras isoladas, pois possibilitou a diferenciação do ortopoxvírus de outros gêneros da família Poxviridae, incluindo o parapoxvírus (Inoshima et al., 2001; Trindade et al., 2003). Um animal que apresentava sinais clínicos foi negativo à soroneutralização e isso foi, provavelmente, atribuído ao curto tempo 
pós-infecção, já que o primeiro caso da doença na fazenda ocorreu em apenas 15 dias (Tab. 2).

Os testes moleculares, PCR seguido do seqüenciamento ou RFLP, utilizando os quatro genes característicos de ortopoxvírus, confirmaram o envolvimento do Vaccinia virus no surto descrito.

A suspensão da vacinação contra varíola humana na década de 70 e a declaração da erradicação dessa doença no mundo contribuíram para que muitos aspectos sobre a ecologia e a manutenção dos ortopoxvírus na natureza, bem como o papel dos hospedeiros reservatórios, fossem negligenciados. Tanto no Brasil, como em outros países da América do Sul, pouco se sabe sobre a circulação de poxvírus e o isolamento de ortopoxvírus silvestres. Nos últimos anos, vários surtos de varíola bovina, em diferentes regiões do Brasil, emergiram como zoonose. Ao que tudo indica, há circulação desses vírus no país e, em muitos casos, a origem das amostras parece estar relacionada à vacina utilizada durante a campanha de vacinação.

\section{REFERÊNCIAS BIBLIOGRÁFICAS}

BREMAN, J.G.; HENDERSON, D.A. Diagnosis and management of smallpox. New Engl. J. Med., v.346, p.1300-1308, 2002.

BULLER, R.M.L.; PALUMBO, G.J. Poxvirus Pathogenesis. Microb. Rev., v.55, p.80 - 122, 1991.

DAMASO, C.R.A.; ESPOSITO, J.J.; CONDIT, R.C. et al. An emergent poxvirus from humans and cattle in Rio de Janeiro State: Cantagalo virus may derive from Brazilian smallpox vaccine. Virology, v.277, p.439449, 2000.

DINIZ, S.; TRINDADE, G.S.; FONSECA, F.G. et al. Surto de varíola murina em camundongos suíços em biotérios: relato de caso. Arq. Bras. Med. Vet. Zootec., v. 53, p. $152-156,2001$.

FAGLIARI, J.J.; PASSIPIERI, M. Relato sobre a ocorrência de pseudovaríola em vacas lactantes e ordenhadores do município de Aparecida do Tabuado, MS. Arq. Inst. Biol., v.66, p.128, 1999 (Resumo).

FENNER, F. Adventures with poxviruses of vertebrates. FEMS Microbiol. Rev., v.24, p.123-133, 2000 .
FENNER, F.; WITTEK, R.; DUMBELL, K.R. The orthopoxviruses. San Diego: Academic, 1989.

FONSECA, F.G.; LANNA, M.C.S.; CAMPOS, M.A.S. et al. Morphological and molecular characterization of the poxvirus BeAn 58058. Arch. Virol., v.143, p.1171-1186, 1998.

FONSECA, F.G.; TRINDADE, G.S.; SILVA, R.L.A. et al. Characterization of a vaccinia-like virus isolated in a Brazilian forest - Short Communication. J. Gen. Virol., v.83, p.223-228, 2002.

INOSHIMA, Y.; MURAKAMI, K.; YOKOYAMA et al. Genetic heterogeneity among parapoxviruses isolated from sheep, cattle and Japanese serows (Capricornis crispus). J. Gen. Virol., v.82, p.12151220, 2001.

LEWIS-JONES, S. Zoonotic poxvirus infections in humans. Curr. Opin. Infect. Dis., v.17, p.81-89, 2004.

MAZUR, C.; FERREIRA, I.I.; RANGEL FILHO, F.B. et al Molecular characterization of Brazilian isolates of orf virus. Vet. Microbiol., v.73, p.253-259, 2000.

MEYER, H.; ROOP, S.L.; ESPOSITO, J.J. Gene for A-type inclusion body protein is useful for a polymerase chain reaction assay to differentiate orthopoxvirus. J. Virol. Meth., v.64, p.217-221, 1997.

MOSS, B. Poxviridae: the viruses and their replication. In: FIELDS, B. N.; KNIPE, D.M.; HOWLEY, P.M. et al. (Eds.). Virology. 4.ed. Philadelphia: Lippincott-Raven, 2001. p.2849-2883.

NAGASSE-SHUGARA， T.K.; KISIELIUS， J.J.; UEDA-ITO, M. et al. Human vaccinia-like virus outbreaks in São Paulo and Goiás States, Brazil: virus detection, isolation and identification. Rev. Inst. Med. Trop. São Paulo, v.46, p.315-322, 2005.

SANGER, F.; NICKLEN,S.; COULSON, A.R. DNA sequencing with chain-termination inhibitors. Proc. Natl. Acad. Sci. USA, v.74, p.5463-5467,1977.

SCHATZMAYR, H. G.; LEMOS, E. R.; MAZUR, C. et al. Detection of poxvirus in cattle associated with human cases in the State of Rio de Janeiro: preliminary report. Mem. Inst. Oswaldo Cruz, v.95, p.625-627, 2000.

SILVA, P.L.; VIANA, F.C.; RIBEIRO, S.C. et al. Surto de varíola bovina no município de Prata - MG. Arq. Bras. Med. Vet. Zootec., v.38, p.323-330, 1986.

TRINDADE G. S.; FONSECA, F. G.; MARQUES, J. $\mathrm{T}$. et al. Araçatuba virus: a vaccinia-like virus associated with infection in humans and cattle. Emerg. Infect. Dis., v.9, p.155-160, 2003. 